\title{
TET2, ASXL1, IDH1, and IDH2 Single Nucleotide Polymorphisms in Turkish Patients with Chronic Myeloproliferative Neoplasms
}

\author{
Kronik Miyeloproliferatif Neoplazi Tanılı Türk Hastalarda TET2, ASXL1, IDH1 ve IDH2 Tek \\ Nükleotid Polimorfizmleri
}

Nur Soyer ${ }^{1}$, Burçin Tezcanlı Kaymaz², Melda Cömert Özkan${ }^{1}$, Çağdaş Aktan², Ali Şahin Küçükaslan², Fahri Şahin ${ }^{1}$, Buket Kosova², Güray Saydam ${ }^{1}$

${ }^{1}$ Ege University Faculty of Medicine, Department of Hematology, Izmir, Turkey

${ }^{2}$ Ege University Faculty of Medicine, Department of Medical Biology, Izmir, Turkey

\section{Abstract}

We aimed to determine the genotype distribution, allele frequency, and prognostic impact of IDH1/2, TET2, and ASXL1 single nucleotide polymorphisms (SNPs) in myeloproliferative neoplasms (MPNs). TET2 (rs763480), ASXL1 (rs2208131), and IDH1 (rs11554137) variant homozygous genotype frequencies were found at rates of 1.5\%, 9.2\%, and $2.3 \%$, respectively. No IDH2 SNP was identified. IDH1 and TET2 frequencies were $5 \%$ in essential thrombocythemia (ET) and 1.7\% in $\mathrm{ET}$ and $5 \%$ in primary myelofibrosis (PMF), respectively. ASXL1 frequencies were $8.3 \%-10 \%$ in MPN subgroups. The TET2 mutant allele $\mathrm{T}$ and $A S X L 1$ mutant allele $\mathrm{G}$ had the highest frequencies with 0.272 in the PMF and 0.322 in the polycythemia vera (PV) group, respectively. There was no impact of the SNPs on prognosis. $I D H 1$ frequency in MPNs was found similar to the literature. ASXL1 frequencies were similar between ET, PV, and PMF patients. The ASXL1 and TET2 allele frequencies of the Turkish population are similar to those of the European population. The role of SNPs in MPNs might be further evaluated in larger multicenter studies.

Keywords: TET2, ASXL1, IDH1, IDH2, Single nucleotide polymorphisms, $\mathrm{Ph}$-negative myeloproliferative neoplasms

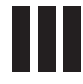

$\ddot{\mathrm{O} z}$

Bu çalışmada biz $A S X L 1, T E T 2, I D H 1 / 2$ genlerindeki tek nükleotid polimorifizmlerin (SNP) alel sıklığını, genotipik dağılımını ve prognostik etkisini saptamayı amaçladık. TET2 (rs763480), ASXL1 (rs2208131) ve IDH1 (rs11554137) varyant homozigot genotip sıklığı sırasıyla $\% 1,5, \% 9,2$ ve $\% 2,3$ saptandı. IDH2 SNP saptanmadı. IDH1 sıklığı ET'de $\% 5$ ve TET2 sıklığı ET'de \%1,7 ve PMF'te $\% 5$ idi. ASXL1 sıklığı ise MPN alt gruplarında \%8,3-10'du. En yüksek TET2 mutant allel T ve ASXL mutant allel G sıklığı sırasıyla PMF'te 0,272 ve PV'de 0,322 olarak saptandı. SNP'lerin prognoz üzerine etkisi yoktu. MPN'de IDH1 sıklığı literatür ile uyumlu bulundu. ASXL1 sıklığı PV, PMF ve ET alt gruplarında benzerdi. Türklerde $A S X L 1$ ve TET2 allel sıklığı Avrupalılar ile benzer saptandı. MPN'lerde SNP'lerin rolü, büyük ve çok merkezli çalışmalarda değerlendirilmelidir.

Anahtar Sözcükler: TET2, ASXL1, IDH1, IDH2, Tek nükleoitid polimorfizm, $\mathrm{Ph}$-negatif Miyeloproliferatif neoplaziler

\section{Introduction}

Philadelphia-negative myeloproliferative neoplasms (MPNs) are clonal disorders classified as polycythemia vera (PV), essential thrombocythemia (ET), and primary myelofibrosis (PMF). MPNs are dependent on hypersensitivity or anomalies in cytokine regulation $[1,2]$. Some genes have been reported to be involved in the pathogenesis of MPNs, such as IDH1 (isocitrate dehydrogenase), IDH2, TET2 (ten-eleven translocation 2), and ASXL1 (additional sex combs-like 1).
$I D H 1 / 2$ encodes enzymes that catalyze the oxidative decarboxylation of isocitrate to $\alpha$-ketoglutarate [3]. The frequency of $I D H 1 / 2$ mutation was $4 \%$ in $\mathrm{MPNs}^{2}, 0.8 \%$ in $\mathrm{ET}, 1.9 \%$ in $\mathrm{PV}$, and $4.1 \%$ in PMF $[4,5]$. These mutations in PMF were reported as independent predictors of leukemic transformation [6].

ASXL1 encodes a member of the chromatin-binding proteins and is involved in epigenetic regulation of gene expression [7]. ASXL1 mutations are rare in ET and PV $(<7 \%)$ but are frequent 
in PMF $(19-40 \%)[3,7]$. Worsened survival was reported in PMF patients with mutated ASXL1 [8].

TET proteins are enzymes that can convert 5-methylcytosine to 5-hydroxymethylcytosine [9]. TET2 mutation frequency was $16 \%$ in $\mathrm{PV}, 5 \%$ in $\mathrm{ET}$, and 17\% in PMF. Previous research did not identify an impact of TET2 mutations on survival or leukemic transformation [10].

Although the prognostic impact of these mutations has been investigated in some studies, there is still limited information available $[6,8,10]$. In this study, we focused only on single nucleotide polymorphisms (SNPs) in the ASXL1, TET2, and IDH1/2 genes. We aimed to determine the genotype distribution, allele frequency, and prognostic impact of selected SNPs in MPNs.

\section{Materials and Methods}

The study included 130 MPN patients. The diagnosis of MPNs was performed based on World Health Organization and International Working Group criteria [11]. The Ege University Local Ethics Committee approved the study (13-5.1/8, 15.07.2013). Patient data were collected from the patient files.

SNP analysis was performed on DNA derived from peripheral blood samples that were collected into tubes containing EDTA between February 2008 and September 2009 and were stored at $-80{ }^{\circ} \mathrm{C}$ until the DNA extraction. DNA extraction was performed using the MagNA Pure Compact Nucleic Acid Isolation Kit (Roche) according to the manufacturer's instructions. After DNA isolation, the purity and concentration of DNA was measured using a NanoDrop spectrophotometer (Thermo Scientific, USA) at $260 \mathrm{~nm}$ and $280 \mathrm{~nm}$.

All SNP analysis was carried out with ready-to-use TaqMan assays from Life Technologies (USA): IDH1 [rs11554137(C/T conversion)], IDH2 [rs121913503-(G/A conversion); rs267606870-(C/G conversion)], TET2 [rs763480-(A/T conversion)], and ASXL1 [rs2208131-(A/G conversion). Realtime polymerase chain reaction (PCR) reactions were performed according to the manufacturer's instructions using the $A B I 7500$ Fast Real-Time PCR instrument (Applied Biosystems, USA). The real-time PCR cycling conditions were: $95{ }^{\circ} \mathrm{C}$ for $10 \mathrm{~min}$ for enzyme activation, 40 cycles of $95^{\circ} \mathrm{C}$ for $15 \mathrm{~s}$ (denaturation), and $60{ }^{\circ} \mathrm{C}$ for $1 \mathrm{~min}$ (annealing/extension). All assays were evaluated and genotyped using SDS software.

\section{Statistical Analysis}

Hardy-Weinberg equilibrium was used for each SNP. All p-values were two sided and $p \leq 0.05$ indicated statistical significance. Categorical and continuous variables were compared with chisquare statistics and the Mann-Whitney $\mathrm{U}$ test, respectively. Survival analysis was performed by the Kaplan-Meier method, taking the interval from the date of diagnosis to death or last contact. The log-rank test was used to compare the survival data.

\section{Results}

The demographic features of patients at the time of diagnosis are shown in Table 1. IDH2 (rs121913503) and IDH2 (rs267606870) SNPs were not detected in any of the patient groups; all of the cases were genotyped as wild-type homozygous ( $\mathrm{GG}$ and $\mathrm{CC}$, respectively, for the rs numbers). Two (1.5\%) of all, 12 (9.2\%) of all, and $3(2.3 \%)$ of all patients were variant homozygous for TET2 (rs763480), ASXL1 (rs2208131), and IDH1 (rs11554137) SNPs, respectively (Table 2).

The TET2 mutant allele T frequency was 0.218 in the PV, 0.20 in the ET, and 0.272 in the PMF group. The ASXL1 mutant allele $\mathrm{G}$ frequency was 0.322 in the PV, 0.308 in the ET, and 0.25 in the PMF group. The IDH 1 mutant allele T frequency was 0.073 in the $P V, 0.108$ in the ET, and 0.045 in the PMF group.

The median follow-up time was 8 years (range: 1-25). The estimated 10 -year survival rate was $71 \%$ for $\mathrm{ET}, 87.3 \%$ for $\mathrm{PV}$, and $71 \%$ for PMF patients (Figure 1). We did not find any significant differences between the diagnostic subgroups and the 10-year survival rates. At the time of the analysis, 5 and 10 patients had leukemic transformation and fibrotic transformation, respectively. There were no significant differences between the sexes, diagnoses, JAK2 mutation status (positive/negative), thrombosis status at diagnosis, survival rates, leukemic and fibrotic transformation, and genotyping results of ASXL1, TET2, and IDH1 (Table 3).

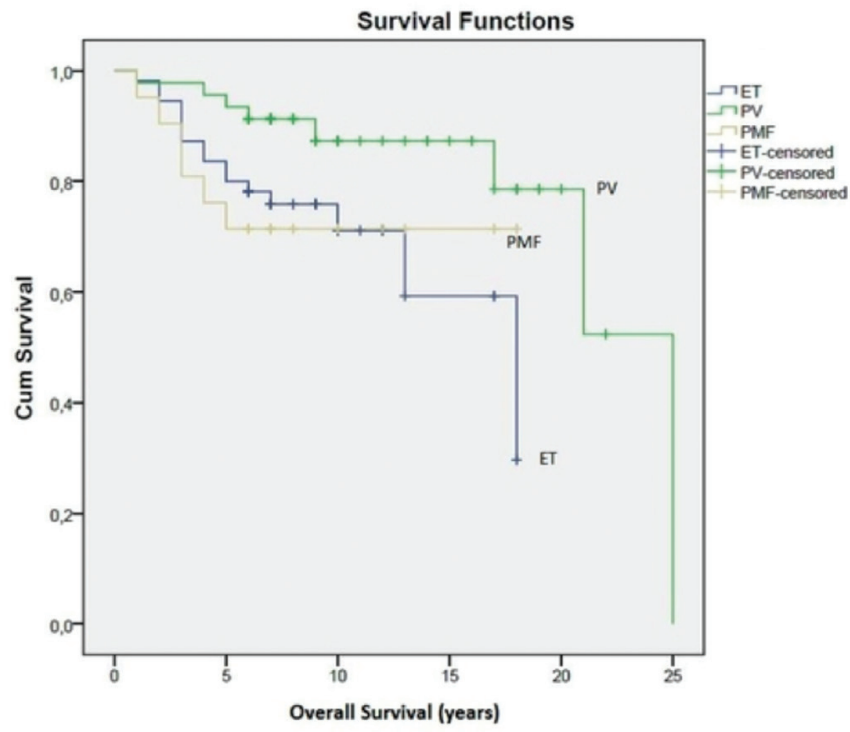

Figure 1. Overall survival of different myeloproliferative neoplasm subgroups.

ET: Essential thrombocythemia, PV: polycythemia vera, PMF: primary myelofibrosis. 


\begin{tabular}{|l|l|l|l|l|}
\hline Table 1. The demographic features of myeloproliferative neoplasm patients at the time of diagnosis. \\
\hline No of patients & MPN (n=130) & PV (n=48) & ET (n=60) & PMF (n=22) \\
\hline Age at diagnosis, years (range) & $63.5(16-81)$ & $63.5(16-74)$ & $63(18-81)$ & $65(31-74)$ \\
\hline Sex, M/F & $72 / 58$ & $30 / 18$ & $29 / 31$ & $13 / 9$ \\
\hline Thrombosis at diagnosis or before diagnosis, yes/no & $19 / 111$ & $6 / 42$ & $10 / 50$ & $3 / 19$ \\
\hline Bleeding at diagnosis, yes & 5 & 2 & 2 & 1 \\
\hline White blood cell count, x109/L (range) & $18.7(3.1-73)$ & $18.7(7.1-40.2)$ & $8.1(4.8-35)$ & $33.9(3.1-73)$ \\
\hline Platelet count, x109/L (range) & $270.7(88-2000)$ & $270.7(95-1380)$ & $906.5(325-2000)$ & $350(88-1436)$ \\
\hline Hemoglobin level, g/L (range) & $18(6-23.4)$ & $18(11.4-23.4)$ & $13.6(8.8-16)$ & $13.8(6-16.2)$ \\
\hline LDH levels, normal/high & $70 / 52$ & $26 / 18$ & $40 / 17$ & $4 / 17$ \\
\hline Splenomegaly, yes/no & $40 / 90$ & $20 / 28$ & $4 / 56$ & $16 / 6$ \\
\hline Hepatomegaly, yes/no & $18 / 112$ & $8 / 40 \mathrm{~V}$ & $3 / 58$ & $8 / 14$ \\
\hline JAK2V617F positive/negative & $87 / 43$ & $46 / 2$ & 2 & $11 / 11$ \\
\hline Secondary malignancies, yes & 2 & 0 & 0 \\
\hline LDH: Lactate dehydrogenase, MPN: myeloproliferative neoplasm, ET: essential thrombocythemia, PMF: primary myelofibrosis. & \\
\hline
\end{tabular}

\begin{tabular}{|c|c|c|c|c|}
\hline & MPN $(n=130)$ & PV $(n=48)$ & ET $(n=60)$ & PMF $(n=22)$ \\
\hline $\begin{array}{l}\text { IDH2 (rs121913503) } \\
\text { Wild-type homozygous }\end{array}$ & 130 & 48 & 60 & 22 \\
\hline $\begin{array}{l}\text { IDH2 (rs267606870) } \\
\text { Wild-type homozygous }\end{array}$ & 130 & 48 & 60 & 22 \\
\hline $\begin{array}{l}\text { IDH1 (rs11554137) } \\
\text { Wild-type homozygous } \\
\text { Heterozygous } \\
\text { Variant homozygous }\end{array}$ & $\begin{array}{l}111(85.4 \%) \\
16(12.3 \%) \\
3(2.3 \%)\end{array}$ & $\begin{array}{l}41(85.4 \%) \\
7(14.6 \%) \\
0(0 \%)\end{array}$ & $\begin{array}{l}50(83.3 \%) \\
7(11.7 \%) \\
3(5 \%)\end{array}$ & $\begin{array}{l}20(90.9 \%) \\
2(9.1 \%) \\
0(0 \%)\end{array}$ \\
\hline $\begin{array}{l}\text { TET2 (rs763480) } \\
\text { Wild-type homozygous } \\
\text { Heterozygous } \\
\text { Variant homozygous }\end{array}$ & \begin{tabular}{|l}
$75(57.7 \%)$ \\
$53(40.8 \%)$ \\
$2(1.5 \%)$
\end{tabular} & $\begin{array}{l}27(56.2 \%) \\
21(43.8 \%) \\
0(0 \%)\end{array}$ & $\begin{array}{l}37(61.7 \%) \\
22(36.7 \%) \\
1(1.7 \%)\end{array}$ & $\begin{array}{l}11(50 \%) \\
10(45.5 \%) \\
1(5 \%)\end{array}$ \\
\hline $\begin{array}{l}\text { ASXL1 (rs2208131) } \\
\text { Wild-type homozygous } \\
\text { Heterozygous } \\
\text { Variant homozygous }\end{array}$ & \begin{tabular}{|l|}
$63(48.5 \%)$ \\
$55(42.3 \%)$ \\
$12(9.2 \%)$ \\
\end{tabular} & $\begin{array}{l}21(43.8 \%) \\
23(47.9 \%) \\
4(8.3 \%)\end{array}$ & $\begin{array}{l}29(48.3 \%) \\
25(41.7 \%) \\
6(10 \%)\end{array}$ & $\begin{array}{l}13(59.1 \%) \\
7(31.8 \%) \\
2(9.1 \%)\end{array}$ \\
\hline
\end{tabular}

\section{Discussion}

In this study, we aimed to determine the genotype distribution, allele frequency, and prognostic impact of selected SNPs in MPNs. IDH mutation frequency was $2.5 \%$ in MPNs, $0.8 \%$ in ET, $1.9 \%$ in $\mathrm{PV}, 4.1 \%$ in $\mathrm{PMF}$, and 1\% in post-ET/PV-myelofibrosis patients [5]. Another study reported 3.70\% IDH1 (G105G allele), 1.85\% IDH2 R1400, and 0.92\% IDH2 (G145G allele) mutation in MPNs [12]. The frequency of the IDH1 (rs11554137) SNP in our cases was similar to that in the literature.

TET2 mutation frequency was 7.2\%-13\% in MPNs and was similar across different MPN subgroups. JAK2-positive patients (17\%) had significantly higher TET2 mutation frequency $[10,13]$.
In our series, TET2 (rs763480) frequency was higher in PMF patients.

ASXL1 mutation frequency was 10\% in MPN patients. These mutations are rare in ET and PV $(<7 \%)$ but frequent in PMF (19\%-40\%) [3,7]. In JAK2- and MPL-negative MPN patients, TET2 and ASXL1 mutation frequencies were 8\% [14]. ASXL1 mutation frequency was $24.7 \%$ in PMF and $8.4 \%$ in ET patients [15]. ASXL1 mutation frequency was 12\%-13\% in PMF patients [16]. The frequency of the ASXL 1 (rs2208131) SNP was 9.2\% and this was similar between ET, PV, and PMF patients. We did not find any previous study that evaluated ASXL1 (rs2208131) and TET2 (rs763480) SNPs in MPNs. 


\begin{tabular}{|c|c|c|c|c|c|c|c|c|c|}
\hline & \multicolumn{2}{|c|}{ IDH1 (rs11554137) } & \multirow[t]{2}{*}{$\mathbf{p}$} & \multicolumn{2}{|c|}{ TET2 (rs763480) } & \multirow[t]{2}{*}{ p } & \multicolumn{2}{|c|}{ ASXL1 (rs2208131) } & \multirow[t]{2}{*}{$\mathbf{p}$} \\
\hline & $\begin{array}{l}\text { Wild-type } \\
(n=111)\end{array}$ & $\begin{array}{l}\text { Heterozygous } \\
\text { and variant } \\
\text { homozygous } \\
(n=19)\end{array}$ & & $\begin{array}{l}\text { Wild-type } \\
(n=75)\end{array}$ & $\begin{array}{l}\text { Heterozygous } \\
\text { and variant } \\
\text { homozygous } \\
(n=55)\end{array}$ & & $\begin{array}{l}\text { Wild-type } \\
(n=63)\end{array}$ & $\begin{array}{l}\text { Heterozygous } \\
\text { and variant } \\
\text { homozygous } \\
(n=67)\end{array}$ & \\
\hline $\operatorname{Sex}(M / F)$ & $61 / 50$ & $11 / 8$ & NS & $37 / 38$ & $35 / 20$ & NS & $31 / 32$ & $41 / 26$ & NS \\
\hline PV & 41 & 7 & NS & 27 & 21 & NS & 21 & 31 & NS \\
\hline ET & 50 & 10 & NS & 37 & 23 & NS & 29 & 27 & NS \\
\hline PMF & 20 & 2 & NS & 11 & 11 & NS & 13 & 9 & NS \\
\hline Thrombosis at diagnosis & 17 & 2 & NS & 11 & 8 & NS & 9 & 10 & NS \\
\hline $\begin{array}{l}\text { JAK2, mutated vs. } \\
\text { wild-type }\end{array}$ & $75 / 36$ & $12 / 7$ & NS & $50 / 25$ & $37 / 18$ & NS & $44 / 19$ & $43 / 24$ & NS \\
\hline $\begin{array}{l}\text { Overall survival } \\
\text { (10-year) }\end{array}$ & $79.8 \%$ & $62.2 \%$ & NS & $75.3 \%$ & $80.4 \%$ & NS & $84.7 \%$ & $70.4 \%$ & NS \\
\hline Leukemic transformation & 4 & 1 & NS & 4 & 1 & NS & 3 & 2 & NS \\
\hline Fibrotic transformation & 9 & 1 & NS & 6 & 4 & NS & 7 & 3 & NS \\
\hline
\end{tabular}

There was no relationship between TET2, IDH1, and ASXL1 SNPs and clinical and laboratory factors in our study. An impact of TET2 mutation on survival and leukemic transformation was not shown [10]. In normal karyotype acute myeloid leukemia, the IDH1 (rs11554137) SNP was an adverse prognostic factor [17]. In PMF, there was a significantly negative impact of IDH mutations on survival [6]. ASXL1 mutations were identified in patients with PMF or post-ET/PV-myelofibrosis and associated with poor survival $[8,9,15]$. Whether the TET2, IDH1, and ASXL1 SNPs possibly confer any prognostic impact in MPN patients requires further evaluation.

The TET2 mutant allele $\mathrm{T}$ and $A S X L 1$ mutant allele $\mathrm{G}$ had the highest frequencies at 0.272 in the PMF and 0.322 in the PV group, respectively. The ASXL1 and TET2 mutational statuses in the Turkish population are similar to those of the European population according to HapMap CEU data reporting $0.322 \mathrm{G}$ mutant allele and $0.372 \mathrm{~T}$ mutant allele frequencies, respectively (hapmap.ncbi.nlm.nih.gov/).

One of the limitations of this study is the small sample size. Since we did not evaluate MPL and CALR mutations, we could not assess whether there was a relationship between $C A L R$ and MPL mutations and these SNPs. Since we had no control group, we could not perform a comparison for these SNPs between patients and controls.

\section{Conclusion}

$I D H 1$ frequency in MPNs was found to be similar to the rate reported in the literature. ASXL1 frequencies were similar between ET, PV, and PMF patients. We did not find an impact of the SNPs on survival, JAK2 status, or leukemic and fibrotic transformation. These findings suggest that $I D H 1$ is a rare SNP in MPNs. The role of SNPs in MPNs might be further evaluated in larger multicenter studies.

\section{Authorship Contributions}

Surgical and Medical Practices: N.S., M.C.Ö., G.S.; Concept: N.S., B.T.K., B.K., G.S.; Design: N.S., B.T.K., B.K., G.S.; Data Collection or Processing: N.S., B.T.K., M.C.Ö., Ç.A., A.Ş.K., F.Ş., B.K., G.S.; Analysis or Interpretation: N.S., B.T.K., Ç.A., A.S..K.; Literature Search: N.S., B.T.K.; Writing: N.S., G.S.

Conflict of Interest: The authors of this paper have no conflicts of interest, including specific financial interests, relationships, and/or affiliations relevant to the subject matter or materials included.

\section{References}

1. Delhommeau F, Pisani DF, James C, Casadevall N, Constantinescu S, Vainchenker W. Oncogenic mechanisms in myeloproliferative disorders. Cell Mol Life Sci 2006;63:2939-2953.

2. Campbell PJ, Green AR. The myeloproliferative disorders. N Engl J Med 2006;355:2452-2466.

3. Tefferi A. Novel mutations and their functional and clinical relevance in myeloproliferative neoplasms: JAK2, MPL, TET2, ASXL1, CBL, IDH and IKZF1. Leukemia 2010;24:1128-1138.

4. Pardanani $A$, Lasho $T L$, Finke $C M$, Mai M, McClure RF, Tefferi A. IDH1 and IDH2 mutation analysis in chronic and blast phase myeloproliferative neoplasms. Leukemia 2010;24:1146-1151.

5. Tefferi A, Lasho TL, Abdel-Wahab 0, Guglielmelli P, Patel J, Caramazza D, Pieri L, Finke CM, Kilpivaara O, Wadleigh M, Mai M, McClure RF, Gilliland 
DG, Levine RL, Pardanani A, Vannucchi AM. IDH1 and IDH2 mutation studies in 1473 patients with chronic-, fibrotic- or blast-phase essential thrombocythemia, polycythemia vera or myelofibrosis. Leukemia 2010;24:1302-1309.

6. Tefferi A, Jimma T, Sulai NH, Lasho TL, Finke CM, Knudson RA, McClure $\mathrm{RF}$, Pardanani A. IDH mutations in primary myelofibrosis predict leukemic transformation and shortened survival: clinical evidence for leukemogenic collaboration with JAK2V617F. Leukemia 2012;26:475-480.

7. Carbuccia N, Murati A, Trouplin V, Brecqueville $M$, Adélaïde J, Rey J, Vainchenker W, Bernard OA, Chaffanet M, Vey N, Birnbaum D, Mozziconacci MJ. Mutations of ASXL1 gene in myeloproliferative neoplasms. Leukemia 2009;23:2183-2186.

8. Brecqueville M, Rey J, Bertucci F, Coppin E, Finetti P, Carbuccia N, Cervera N, Gelsi-Boyer V, Arnoulet C, Gisserot O, Verrot D, Slama B, Vey N, Mozziconacci MJ, Birnbaum D, Murati A. Mutation analysis of ASXL1,CBL, DNMT3A, IDH1, IDH2, JAK2, MPL, NF1, SF3B1, SUZ12, and TET2 in myeloproliferative neoplasms. Genes Chromosomes Cancer 2012;51:743-755.

9. Abdel-Wahab 0, Tefferi A, Levine RL. Role of TET2 and ASXL1 mutations in the pathogenesis of myeloproliferative neoplasms. Hematol Oncol Clin North Am 2012;26:1053-1064.

10. Tefferi A, Pardanani A, Lim KH, Abdel-Wahab O, Lasho TL, Patel J, Gangat N, Finke CM, Schwager S, Mullally A, Li CY, Hanson CA, Mesa R, Bernard O, Delhommeau F, Vainchenker W, Gilliland DG, Levine RL. TET2 mutations and their clinical correlates in polycythemia vera, essential thrombocythemia and myelofibrosis. Leukemia 2009;23:905-911.

11. Tefferi A, Vardiman JW. Classification and diagnosis of myeloproliferative neoplasms: the 2008 World Health Organization criteria and point-of-care diagnostic algorithms. Leukemia 2008;22:14-22.
12. Chotirat S, Thongnoppakhun W, Wanachiwanawin W, Auewarakul CU. Acquired somatic mutations of isocitrate dehydrogenases 1 and 2 (IDH1 and IDH2) in preleukemic disorders. Blood Cells Mol Dis 2015;54:286-291.

13. Patriarca A, Colaizzo D, Tiscia G, Spadano R, Di Zacomo S, Spadano A, Villanova I, Margaglione $M$, Grandone $E$, Dragani A. TET2 mutations in Ph-negative myeloproliferative neoplasms: identification of three novel mutations and relationship with clinical and laboratory findings. Biomed Res Int 2013;2013:929840.

14. Martínez-Avilés L, Besses $C$, Álvarez-Larrán $A$, Torres $E$, Serrano $S$, Bellosillo B. TET2, ASXL1,IDH1, IDH2, and C-CBL genes in JAK2- and MPL-negative myeloproliferative neoplasms. Ann Hematol 2012;91:533-541.

15. Yonal-Hindilerden I, Daglar-Aday A, Akadam-Teker B, Yilmaz C, Nalcaci M, Yavuz AS, Sargin D. Prognostic significance of ASXL1, JAK2V617F mutations and JAK2V617F allele burden in Philadelphia-negative myeloproliferative neoplasms. J Blood Med 2015;6:157-175.

16. Abdel-Wahab O, Pardanani A, Patel J, Wadleigh M, Lasho T, Heguy A, Beran $M$, Gilliland DG, Levine RL, Tefferi A. Concomitant analysis of EZH2 and ASXL1 mutations in myelofibrosis, chronic myelomonocytic leukemia and blast-phase myeloproliferative neoplasms. Leukemia 2011;25:1200-1202.

17. Wagner K, Damm F, Göhring G, Görlich $K$, Heuser M, Schäfer I, Ottmann O, Lübbert $M$, Heit W, Kanz L, Schlimok G, Raghavachar AA, Fiedler $W$, Kirchner HH, Brugger W, Zucknick M, Schlegelberger B, Heil G, Ganser A, Krauter J. Impact of IDH1 R132 mutations and an IDH1 single nucleotide polymorphism in cytogenetically normal acute myeloid leukemia: SNP rs11554137 is an adverse prognostic factor. J Clin Oncol 2010;28:23562364. 